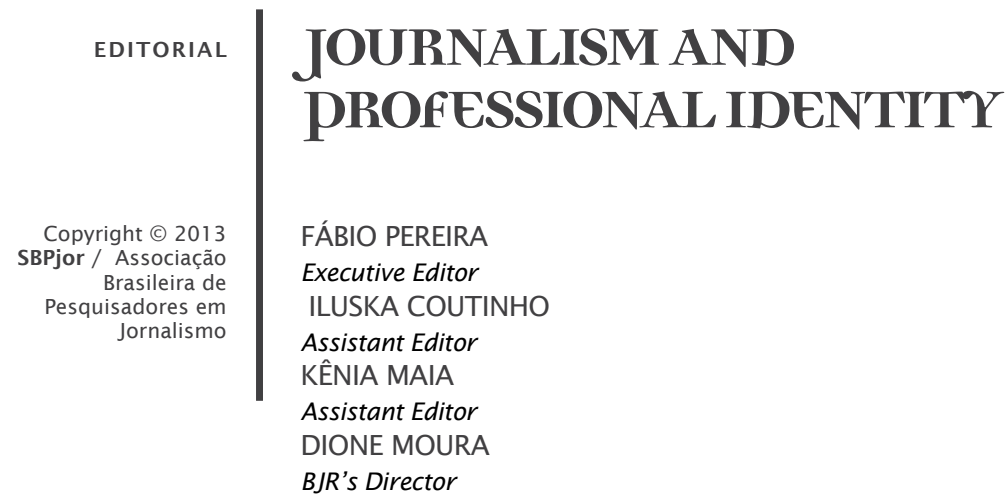

Historically, studies on journalism in Brazil have given little attention to the issue of professional identity - see especially the bibliometric surveys of Machado (2004), Meditsch, Segala (2005) and Moura (2012). It is usually discussed in a tangential way, often from a normative or functionalist view about the journalist: as a mediator, informer or representative of the Fourth Estate.

At the same time, there is a proliferation of debates, frequently counting on the participation of universities, about the role of journalists in different sectors of civil society. It applies to the discussions on higher education in Journalism as a requirement for the professional practice, the debate on the new curriculum guidelines of Journalism courses or the impacts caused by the Access to Information Act, as well as changes in the form of getting and consuming news.

Thus, in 2013 we decided to resume professional identity discussions in the studies about Brazilian journalism. The objective was to promote an international and interdisciplinary dialogue on the topic, to map out research trends and to encourage the construction of new objects of study on the subject. We highlight four related initiatives which involved the direct participation of SBPJor.

First, the support of the Association in carrying out the II International Colloquium on Structural Changes in Journalism, with the theme "Journalism and Professional Identity". Second, SBPJor's support and participation in the survey "Brazilian Journalism Profile", coordinated by Jacques Mick and UFSC team, whose results were published in 2013 by the publisher Insular. The third one was the realization of a panel discussion during the 11th SBPJor Meeting in Brasilia. And fourth, the launch of a call for papers for this issue of BJR, whose dossier's theme is 
"Journalism and Professional Identity".

The response of Brazilian and international academic community to these four initiatives has exceeded our expectations, due to the quantity and quality of works, their theoretical and methodological diversity and the geographic distribution of these researches in Brazil and other countries.

The renewed interest from academic community about journalists identity, in some cases, comes from the perception that there was a reconfiguration of news production processes, especially upon the arising of digital media, which could explain the circulation of a significant number of works that question the profile of this professional in times of technological convergence.

But there is also a large group of researchers interested in the topic, without directly linking it to the technological issue. In this sense, it seems that path opened by SBPJor was critical to ensure visibility to a relatively muted theme in the set of researches on journalism.

This profusion of studies is reflected in a very particular way throughout the editing process of this BJR issue. In total, the magazine received 46 articles, mostly directed to the dossier "Journalism and Professional Identity". Works from the five regions of Brazil and articles from Argentinean, Belgian, Canadian, French and Portuguese authors were submitted. Eight texts are published in this issue.

The texts reveal a diversity of objects and perspectives about journalism. Identity is a central theme of some reflections, but it is often seen transversely, as a possible route of entry for broader discussions on journalistic practices. The dossier presents the interweaving of qualitative and ethnographic methodologies, textual analysis and documentary researches. We also observed a tension between discussions that refer to a scenario of identity reconfigurations - caused by new products and processes - and a relative stability with respect to the values of the profession.

\section{THE DOSSIER}

To open the dossier "Journalism and Professional Identity", we present the article "Journalistic activity on mobile platforms. A study on autochthonous products and changes to the journalist's professional profile", signed by Suzana Barbosa (Universidade Federal da Bahia UFBA), Fernando Firmino (UFBA and Universidade Estadual da Paraíba), Leila Nogueira (UFBA and Universidade Federal do Recôncavo da Bahia) and Yuri Almeida (UFBA). The text analyzes the versions for tablets of 
three newspapers (Globo a Mais, Estadão Noite and Folha10). The results point out to changes in the profile of the professionals involved with the production strategies for these devices. Then the articles "Technological convergence and the new journalist", by David Renault (Universidade de Brasília) and "Professional convergence: a case study on changes in the journalist's profile", by Jan Alyne Barbosa, Lourdes Pereira and Rodolfo Ribeiro (Universidade Federal do Piauí / Universidade Federal da Bahia) propose qualitative studies on the so-called multitasking journalist, referring to the impact of this new profile in professional identity.

Two articles discuss the situation of journalists upon the rise of social networks. "Critical journalism: the "progressive" Brazilian bloggers case", by Liziane Soares Guazina (Universidade de Brasília), investigates the professional values of 'dirty' journalists, responsible for independent blogs and practicing journalism in which they express and defend their opinions and political positions. Natalia Raimondo Anselmino and Mauro Bertone, from Universidad Nacional de Rosario, discuss the changes in the journalistic work through an analysis of how the online versions of the Argentinean dailies Clarín and La Nación incorporate specific resources of social media to their interfaces. At the same time, these newspapers define management strategies for their official profiles on Facebook and Twitter, aiming to a viral distribution of content and the creation of a more direct contact with the audience.

Following this same line - the reconfiguration of journalist's role in times of new relationships with the audience -, we publish two articles that take the telejournalism production as the object of study: "Television newscast news production: the transformation of the news process and professional routines", by Samira Moratti Frazão and Antonio Brasil, from Universidade Federal de Santa Catarina, and "Popular participation and news values in telejournalism: interaction and citizenship", by Adriana Moraes, Ana Carolina Rocha Pessoa Temer and Bernadete Coelho, from Universidade Federal de Goiás. In their conclusions, the authors of both articles highlight the adaptations that news vehicles are performing to increase reader's participation, while it is possible to observe a tendency to strengthen the instruments for controlling and checking content and (re) legitimizing the role of the journalist in mediating this process.

"Ethical dilemmas and production of Journalism: technology insights", authored by Edgard Patrício (Universidade Federal do Ceará), is based on a set of interviews with 15 journalists from Fortaleza to discuss how changes in journalism production - as of the insertion of communication technologies in newsrooms - impact the ethical 
dimension of the profession. The dossier finishes with the article written by Milton Julio Faccin e Soraya Venegas Ferreira (Universidade Estácio de Sá), "Journalism in new clothes: Considerations on the identity and professional practice based on Prêmio Imprensa Embratel". Leaning on a Bourdieusian perspective, the authors analyze how the guidelines of journalists-aimed awards, particularly Embratel, refer to aspects of professional identity. The conclusion is that, despite a backdrop of changes in journalistic practices, awards still legitimate aspects of the 'old paradigm' of the profession, "highlighting the role of social media as a watchdog of the government, as well as a spokesperson of complaints about social conditions that require changes."

\section{OPEN SUBJECT ARTICLES}

In this issue, we also bring four open subject articles. "Does community participation set the local press agenda? A view on deliberative and civic practices in the Portuguese press", signed by Gil Baptista Ferreira, from Escola Superior de Educação de Coimbra, discusses the relationship between journalism and democracy through a questionnaire applied to 45 journalists from leading regional newspapers in Portugal. The author analyzes the representations that journalists make about the role of citizens in democratic life. The results show that, despite respondents value some principles of public and deliberative journalism, there is still a "conventional journalistic approach, which means a perception of journalistic content too focused on the elites and commercial concerns".

Science is the object of analysis in the last three articles of this BJR issue. "Scientific dissemination discourse - a study of specialized magazines disseminating science to lay audiences", by Elizabeth Moraes Gonçalves, from Universidade Metodista de São Paulo, and "Pages of revolution, promise and hope: metaphors of cloning and stem cell research in Brazilian newspapers", by Flavia Natércia da Silva Medeiros, from Universidade Estadual de Campinas, have a focus on the practice of science journalism. The first one shows how the basis of the discursive constructions in three magazines (Scientific American Brasil, Pesquisa Fapesp and Superinteressante) vary according to the editorial commitment they establish with their readers. The second one is also a discourse analysis, but, this time, on metaphors used by the newspapers O Globo, O Estado de S. Paulo and Folha de S. Paulo to address the discussions on cloning and stem cell research.

Janara Sousa and Davi de Castro, from Universidade de Brasília, 
write about the relationship between Science and Journalism from another perspective: how reception studies on the web have been treated by the Brazilian academic production. In the article "The paths of reception: an analysis of the Brazilian scientific production", the authors propose a bibliometric analysis of scientific articles published between 2005 and 2011 in the top seven journals evaluated by Qualis system, from Capes, an agency linked to the Brazilian Ministry of Education in charge of promoting high standards for post-graduate courses in Brazil. The results show that studies on online journalism had the merit to give a new breath to the topic of reception, which was previously relegated to the backseat in the scientific production. "Whether they take a critical or an enthusiastic view, researchers agree on one thing: reception has changed," the authors conclude.

This issue of Brazilian Journalism Research is being released a few weeks after the celebrations of SBPJor's 10th anniversary. For us, journal staff, it was an honor to participate in an issue that, in some ways, also celebrates the success of the Association. Again, we had the support from the Editorial Board members and a group of consultants from Brazilian and foreign institutions. Finally, we expect this edition to share, with the readers of BJR, a bit of our enthusiasm.

\section{REFERENCES}

MACHADO, M. B. Pesquisa em Jornalismo no Brasil: dados e reflexões sobre três ambientes. II ENCONTRO NACIONAL DE PESQUISADORES EM JORNALISMO - SBPJOR. Salvador, novembro de 2004. Anais... SBPJor: Salvador, 2004.

MEDITSCH, E.; SEGALA, M. Trends in three 2003/4 journalism academic meetings'. Brazilian Journalism Research, vol 1, n 1, 2005, p. 47-60.

MOURA, D. O. . A notícia na composição do corpus da pesquisa em jornalismo. In: PEREIRA, F. H.; MOURA, D. O.; ADGHIRNI, Z. L. (Orgs.). Jornalismo e Sociedade: Teorias e Metodologias. Florianópolis: Insular, 2012, p. 15-38. 
JOURNALISM AND PROFESSIONAL IDENTITY 